\title{
THE EFFECTIVENESS OF USING VISUAL AIDS TO PROMOTE SPEAKING SKILLS FOR THE 12TH GRADERS AT CAM PHA HIGH SCHOOL
}

\author{
Nguyen Thi Nhung ${ }^{1 *}$, Nguyen Thi Duong ${ }^{2}$ \\ ${ }^{I} T N U$ - School of Foreign Languages \\ ${ }^{2}$ Cam Pha high school Quang Ninh
}

\section{ABSTRACT}

This study is an attempt to investigate the use of visual aids in teaching speaking to 12 graders at Cam Pha high school. The main purposes of the study are to find out: the current English speaking teaching and learning situation at Cam Pha high school; activities and techniques of teaching with visual aids applied by teachers and students' preferences; the difficulties in learning and teaching English speaking and then give some suggestions for teachers to stimulate students in speaking and overcome the difficulties they have to face with in teaching speaking English for students. The study adopts action research approach, with the use of mixed research methods involving both qualitative and quantitative data. Two hundred $12^{\text {th }}$ grade students and four teachers took part in the study. The findings show that the use of visual aids significantly enhanced students' interest and engagement in speaking skills. Students also reported their improvement in various aspects of speaking skills. The study proposes implications and suggestions for using visual aids in improving speaking skills.

Keywords: The effectiveness; visual aids; speaking skills; the 12th graders; high school students.

Received: 26/7/2019; Revised: 20/8/2019; Published: 28/8/2019

\section{HIỆ QUẢ CỦA VIÊCC SỬ DỤNG GIÁO CỤ TRỰC QUAN ĐỂ PHÁT TRIỂN KỸ NĂNG NÓI CHO HỌC SINH LỚP 12 Ở THPT CẢM PHẢ}

\author{
Nguyễn Thị Nhung ${ }^{*}$, Nguyễn Thị Dương ${ }^{2}$ \\ ${ }^{1}$ Khoa Ngoại ngũ - ĐH Thái Nguyên \\ ${ }^{2}$ Truoòng THPT Cẩm Phả - Quảng Ninh
}

\section{TÓM TẮT}

Nghiên cứu này là một nỗ lực để điều tra việc sử dụng các phương tiện trực quan trong việc dạy nói cho học sinh lớp 12 tại Trường Trung học Cẩm Phả. Mục đích chính của nghiên cứu là tìm hiểu: tình hình dạy và học nói tiếng Anh hiện nay tại Trường Trung học Cẩm Phả; các hoạt động và kỹ thuật giảng dạy với các phương tiện trực quan được giáo viên và học sinh áp dụng theo sở thích; những khó khăn trong việc học và dạy nói tiếng Anh và sau đó đưa ra một số gợi ý cho giáo viên để kích thích học sinh nói và vượt qua những khó khăn mà họ phải đối mặt trong việc dạy nói tiếng Anh cho học sinh. Nghiên cứu áp dụng phương pháp nghiên cứu hành động, với việc sử dụng các phương pháp nghiên cứu hỗn hợp liên quan đến cả dữ liệu định tính và định lượng. Hai trăm học sinh lớp 12 và bốn giáo viên đã tham gia vào nghiên cứu. Các phát hiện cho thấy rằng việc sử dụng các phương tiện trực quan giúp học sinh tăng cường đáng kể sự quan tâm và tham gia vào các kỹ năng nói. Học sinh cũng báo cáo sự cải thiện của họ về các khía cạnh khác nhau của kỹ năng nói. Nghiên cứu đề xuất ý nghĩa và đề xuất sử dụng các phương tiện trực quan trong việc cải thiện kỹ năng nói.

Từ khóa: Sụ hiệu quả; đồ dùng trục quan; kỹ năng nói; học sinh lớp 12; học sinh trung học.

Ngày nhận bài: 26/7/2019; Ngày hoàn thiện: 20/8/2019; Ngày đăng: 28/8/2019

\footnotetext{
* Corresponding author. Email: ntnhungknn@gmail.com

DOI: https://doi.org/10.34238/tnu-jst.2020.03.1868
} 


\section{Introduction}

In Vietnam, English is considered as a foreign language. It also has been introduced to educational institutions, which is learnt from Junior High School up to university as a compulsory subject.

Oral communication competence or speaking skill is the goal of English learning in many schools. Speaking skill is considered as an initial skill that leads learners to develop the other communication competences (reading and writing). However, it is assumed that developing speaking skill to 12th graders in our school is not easy because of the status of English as a foreign language in which it is not used in national or social life.

Supiyati [1] stated that practically the use of visual aids is one of the appropriate techniques to develop students' speaking skills. Actually, there are many kinds of visual aids that the researcher will describe like a picture, graphic, chart, illustrations, etc. Through visual aids, the students are more enthusiastic. Students enjoyed the process of teaching and learning more. Teaching speaking using visual aids gives a big chance to the students to speak. Due to the identified issues of speaking skills of high school students in Vietnam and the effects of employment of group work on enhancing the students' speaking skill, this research employs the treatments of action research to conduct the research on: "The effectiveness of using visual aids to promote speaking skill for the 12th graders at Cam Pha high school".

\section{Literature review}

\subsection{Micro and macro skills of speaking}

In teaching speaking, teachers also help students to learn micro skills and macro skills of speaking, as stated by Brown [2].

Those micro and macro skills above can be a checklist of objective when assessing spoken language. Teachers should pay attention to these when they are teaching speaking skills.

\subsection{Fluency and accuracy}

According to Riddell [3], the ability to talk fairly freely, without too much stopping or hesitating is called fluency. It requires the listener to understand what is being said, so there must be intelligibility and meaning. With accuracy the emphasis is on "correct English" - the right grammar, the right vocabulary. Both fluency and accuracy are equally important. But Riddell has a different thought. It actually depends on what the teachers are teaching. If they teach a high-level student who is about to take an exam to enter college, accuracy is very important indeed.

\section{Teaching and learning speaking skills}

Kimble and Garmezy in Brown [2] state that learning is a relatively permanent change in a behavioral tendency and is the result of reinforced practice. While teaching is showing or helping someone to learn how to do something, giving instructions, guiding in the study of something, providing with knowledge, causing to know or understand.

Brown [2] breaks down the components of the definition of learning, and extract the domains of research and inquiry: Learning is acquisition or "getting", learning is retention of information or skill, retention implies storage systems, memory, and cognitive organization, learning involves active, conscious focus on and acting upon events outside or inside the organism, learning is relatively permanent but subject to forgetting, learning involves some form of practice, perhaps reinforced practice and learning is a change in behavior. Brown also cites that teaching is guiding and facilitating learning, enabling the learner to learn, setting the conditions for learning.

\subsection{Visual aids}

This section refers to the contributions and descriptions some authors give to the concept of visual aids it description and classification. Visual aids have been used since the 
beginning of learning and teaching. Most early reviews were concerned with the meaning of visual aids. As there are many authors who refer to visual aids, this literature review attempts to define them from manifold different points of view, thus provide the audience with complete and varied information. NON-Projected 2D: wall board, roll-up board, picture, poster, chart, cartoon, cue sheet, flannel board, flash card.

\subsection{Use of visual aids in language teaching and learning}

Visual aids evoke the learners interest and help teachers explain concepts easily. Visual support is the instructional support that is used in the classroom to encourage instructional learning speaking. As Singh [4] defines that any device with vision and sound enhances individual practice, in fact achieved through speaking as a visual aids device. Visual support is the teaching device used in the classroom to encourage learning speaking and make it easier and more motivating. Materials such as models, charts, strips, projectors, radios, televisions, maps, etc. are called teaching aids.

\section{Methodology}

\subsection{Research questions}

1. How do visual aids promote speaking skills for the 12th graders at Cam Pha high school?

2. What are Cam Pha high school students' perceptions of and attitudes toward using visual aids in speaking lessons?

3. What are Cam Pha high school teachers' attitudes toward using visual aids in speaking lessons?

\subsection{Participants}

\section{Students}

There are 200 students who participated in this current research; they are students of $12 \mathrm{~A} 1,12 \mathrm{~A} 2,12 \mathrm{~A} 3$, and $12 \mathrm{~A} 4$ at Cam Pha high school. The students are aged from 16 to 18 years old and have learned English for at least nine years. The students share the similar background concerning culture, education and living conditions.

\section{Teachers}

In public high school in Vietnam, each teacher may be responsible for one or more classes; in this current study, four teachers are in charge of English subject for 12A1, 12A2, $12 \mathrm{~A} 3$, and $12 \mathrm{~A} 4$ class respectively. All teachers participating in the research are female. Two teachers have 8 years of experience as high school English teachers while one teacher has 5 years of experience.

\subsection{Data collection instruments}

In gaining the data, the researcher collected the data by using some data collection techniques as follows: Questionnaire; Observation; Interviews.

\subsection{Data collection}

In this research, the data are collected from the questionnaires. Qualitative data deals with any occurrences and changes happen during classroom activities. Students' behaviour, classroom situation, and the process of classroom activity are the examples of qualitative data. The researcher collected qualitative data by using observation, field notes, and interview.

\subsection{Data collection instruments}

In gaining the data, the researcher collected the data by using some data collection techniques as follows: Questionnaire; Observation; Interviews.

\subsection{Data analysis}

The data were in the form of observation sheets, questionnaires, interview transcripts and students' speaking scores. The researcher used the qualitative and quantitative descriptive analysis to analyze the data. There are some useful steps to get an overall framework for the analysis according to Brown [2]: Assembling the data; Coding the data; Comparing the data; Building interpretations; Reporting the outcomes. 


\section{Findings and discussions}

\subsection{Students' purposes of learning speaking English}

Table 1. Students' Purposes of Learning Speaking English

\begin{tabular}{lcc}
\hline \multicolumn{1}{c}{ Purposes } & Students & $\begin{array}{c}\text { Percentage } \\
(\%)\end{array}$ \\
\hline to pass the exam & $112 / 200$ & 56 \\
to communicate to foreigners & $14 / 200$ & 7 \\
to get high mark & $28 / 200$ & 14 \\
to find a job easier & $36 / 200$ & 18 \\
to study abroad & $10 / 200$ & 5 \\
\hline
\end{tabular}

Table 1 reveals that passing the English speaking test is key term for students to learn speaking English. It is understandable that because English is a compulsory subject in the syllabus, the highest percentage (56\%) of students wish to pass the final exam. Finding a future job easier is main purpose of $18 \%$ of students when they joined in the speaking class. About $14 \%$ of the respondents answered that they learned English speaking because of high mark. The others (7\%) wanted to learn English because they would like to communicate with foreigners. Clearly, most of the students knew the role of English in the modern life when foreign language was considered the main means of communication. The lowest percentage $(5 \%)$ of the students affirmed they wanted to study abroad in the future though so far they had not known whether they could achieve their wishes or not; and that was the reason they tried to learn English.

\subsection{Students' assessment on the importance of speaking English}

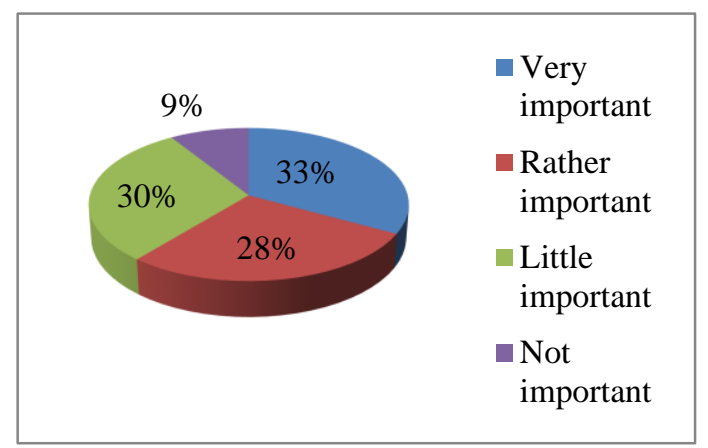

Figure 1. Students' assessment on the importance of speaking English
As can be seen from Figure 1, the highest percentage of the respondents (33\%) considered speaking skill very important to them while $28 \%$ stated it was rather important. In general, the importance of English speaking was highly evaluated by a majority of the students. Most of them were aware of the importance of English in their studying. $30 \%$ of the students thought English speaking skill was a little important and the rest ones of 9\% considered English speaking not important at all.

\subsection{Students' opinions towards speaking English activities}

Figure 2 reveals that the majority of the students (32\%) were quite interested in learning speaking. $18 \%$ of the students had low interest. This figure was a little higher than those with the high one (9\%). 12 out of 43 students (27\%) answered that their interest was normal. For them, they learnt English because of the pressure from outside such as requirement of the teachers and parents, the need for the exam...not because of their willingness. The lowest percentage of the respondents (14\%) affirmed their interest was very low. They were the students who had no interest in learning speaking English.

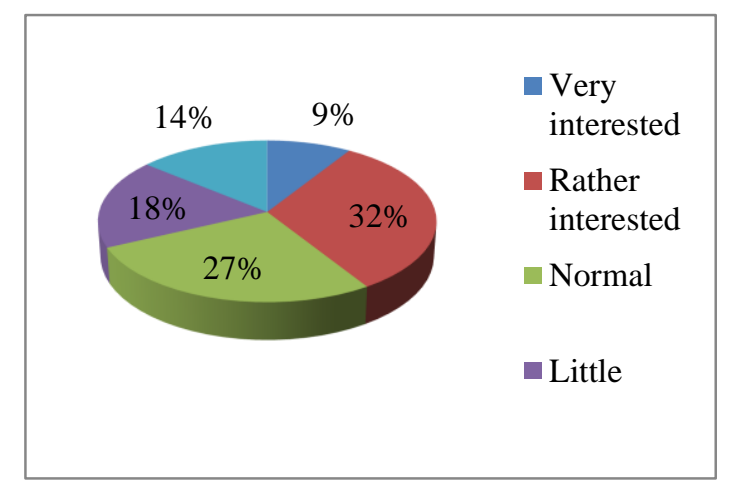

Figure 2. Students' Interest in Learning Speaking English

4.4. Students' frequency of speaking English in speaking class

The frequency of speaking English in class time also shows how much effort students wanted to master it. Figure 3 represents that 
only $22 \%$ of the respondents spoke English willingly, only 10 out of 43 students were always willing to speak English and $16 \%$ of the participants said that they usually spoke English in class; whereas 9\% rarely spoke it and 5\% never spoke English in class except from the teacher's requests. Also, $48 \%$ of the students affirmed they liked speaking but sometimes, they were not accustomed to speaking in class because of their shyness or worrying about making mistakes.

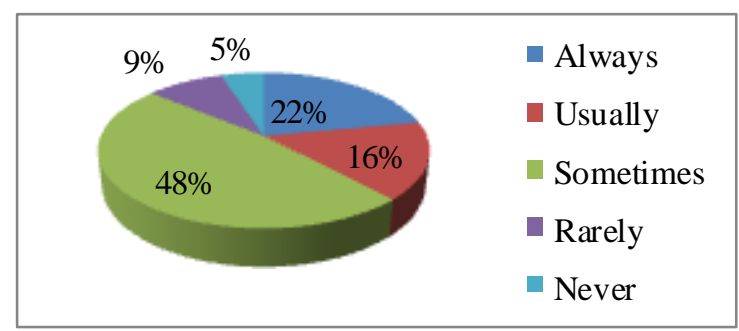

Figure 3. Students' frequency

of speaking English in class time

\subsection{Causes of students' reluctance to speak in class}

Table 2. Factors making students reluctant to speak English in class

\begin{tabular}{lcc}
\hline \multicolumn{1}{c}{ Factors } & Students & $\begin{array}{c}\text { Percentage } \\
(\%)\end{array}$ \\
\hline Learning goal is not to & 100 & 50 \\
communicate & 150 & 75 \\
Being afraid of losing faces & 118 & 59 \\
Boring topics & 80 & 40 \\
Boring teaching ways & 154 & 77 \\
Low proficiency in English &
\end{tabular}

There are learners' factors, teachers' factors, teaching, and learning conditions that make learners unwilling to speak. Here the researcher only mentions two factors: learners' factors and teachers' factors. For students in the survey, the most influential factor was students' low proficiency in English. 154 out of 200 students (77\%) blamed their reluctance of speaking for low proficiency in English. In the small talk with the researcher, some of the students stated: "I like speaking English. But I sometimes cannot find words and structures to express my ideas". Another complained: "My English is not very good. That is why I am not willing to speak in class". The second factor was being afraid of losing faces. $75 \%$ of the respondents affirmed that they wanted to speak in class, but they were always afraid of making mistakes and losing faces. The next one $(59 \%)$ was boring topics. $40 \%$ of the students stated their teachers' teaching way makes them difficult in speaking. The number of the students $(50 \%)$ mentioned to their learning goal was not to communicate.

In short, there are a variety of factors that the students had to face with. These factors came from students as well as teachers. In order to be better in English speaking activities in class, the changes need to be done between both teachers and students. Teachers change teaching methods and students change the way they learn.

\subsection{Students' attitude toward using visual aids in the speaking lesson}

Table 3. Students' opinion of the speaking lessons using visual aids

\begin{tabular}{lcc}
\hline \multicolumn{1}{c}{ Opinion } & Students & $\begin{array}{c}\text { Percentage } \\
(\mathbf{\%})\end{array}$ \\
\hline Too difficult & $40 / 200$ & 20 \\
Challenging but interesting & $132 / 200$ & 66 \\
Normal & $28 / 200$ & 14 \\
Too easy & $0 / 200$ & 0 \\
\hline
\end{tabular}

As can be seen from Table 3, 66\% of the students found using visual aids in the speaking lessons interesting because there are some big challenges to them. However, $20 \%$ of the students had difficulty in using visual aids. There were only a small number of the students (14\%) who stated that using visual aids is not too difficult. No one said that using visual aids is too easy. These facts demonstrate that using visual aids had certain good influence on the students' learning attitude so that they could achieve their goals and gain confidence in English speaking skill.

The result shows the students' interests in speaking with visual aids. After a 12 week intervention with the use of visual aids, students seemed to become more interested in 
speaking lessons. When being asked whether they like speaking with projects, most of the students responded "Yes" (account for 89\%) which is a positive sign. The number of students who did not give any idea is 4 which made up 9\%. Only one student (took up 2\%) chose "No" to the question.

The complementing project made students more enjoyable and interested the speaking class.

The results show that the number of participants who chose "very effective" when being asked about the ways visual aids were used in speaking lesson was $69 \%$ which was much larger than the number of participants who said " ineffective" which made up only $3 \%$. Those who stated that visual aids were "effective" constituted $17 \%$. The rest of the students chose "slightly effective" for their answer which accounted for $11 \%$.

Which aspects of speaking skill have you improved?

Table 4. Criteria of students' speaking skill improved

\begin{tabular}{lcc}
\hline \multicolumn{1}{c}{ Criteria } & Students & $\begin{array}{c}\text { Percentage } \\
(\%)\end{array}$ \\
\hline Fluency & $4 / 200$ & 2 \\
Vocabulary & $2 / 200$ & 1 \\
Grammatical accuracy & $3 / 200$ & 1.5 \\
Pronunciation & $5 / 200$ & 2.5 \\
Interactive communication & $2 / 200$ & 1 \\
All of them & $182 / 200$ & 91 \\
\hline
\end{tabular}

The data in the table 4 shows most of the students $(91 \%)$ have made much progress in their English speaking skill thanks to the lessons using visual aids. All criteria of English speaking skill including fluency, vocabulary, grammatical accuracy, pronunciation, interactive communication met expectations.

\subsection{The role of visual aids in teaching speaking}

Taking up the most proportion, 62\% of informants agreed that it was important to use visual aid to teach English speaking class, in which 4 teachers $(50 \%)$ said that it was important and only 1 teacher (12\%) said that it was very important to apply visual aids in speaking classes. Only 1 teacher $(12.5 \%)$ thought that the use of visual aids to teaching speaking was rather important, and 2 teachers (25\%) denied the importance visual aids.

\subsection{Teachers' frequency of using visual aids in speaking lesson}

Table 5. Teachers' opinions for the frequency of using visual aids

\begin{tabular}{lcc}
\hline \multicolumn{1}{c}{ Frequency } & Occurrence & Percentage (\%) \\
\hline Always & $1 / 4$ & 25 \\
Usually & $1 / 4$ & 25 \\
Sometimes & $2 / 4$ & 50 \\
Rarely & $0 / 4$ & 0 \\
Never & $0 / 4$ & 0 \\
\hline
\end{tabular}

Table 5 indicates that the opinions of the teachers for the frequency of using visual aids are quite varied. To be specific, a number of teachers applied visual aids always were the same ones applied it rarely; a hefty percentage of $50 \%$ wished for it sometimes; $25 \%$ wanted it usually; and no one said never to it.

\subsection{Observations}

In terms of the students, in the first observation students' talk was hesitant, halting, full of pauses and lacked the required fluency and accuracy. Even their responses did not reflect a genuine mental and language ability. In addition, the students' high mental skills, intimate relations and equal participation between males and females.

Concerning the teacher's performance, in the first observation, the traditional teaching aids that were only confined on board, markers and course books, the use of text-related questions that encourage only memorization and the direct error correction without giving any wait times for students to think before speaking. Although the teacher was motivated, she seemed more traditional and teacher centered. The teacher got a fair score of $58 \%$ when he started to apply visual aids in the teachinglearning processes while the students were not yet improved. After the treatment, she got a better score of $75 \%$ because she had prepared his material and improved his teaching. The teaching-learning process became much better and had resulted in a very good.

\subsection{Interviews}

It can be implied that the students actively involved for the activities with visual aids and they were enthusiastic during the teaching and learning process. It also supported by the result 
of interview with the students in the following: "I am eager to speak with visual aids given by the lecturer in speaking class because it is challenging activities and assist me to cooperate with my friend in a group. Visual aids can promote me deeper thinking and build overall critical thinking skills. In fact, bringing a visual aid into your classroom opens up a whole new realm of educational opportunities."

\subsection{Implications}

Students' achievement in speaking which was measured quantitatively increased. It was known questionnaires. It showed that there were improvements in their result. Besides, it was also qualitatively increased. It could be seen from their improvement of vocabulary and active involvement during the speaking class which was identified through interviews and observations.

\section{Conclusion}

By using visual aids, the researcher succeeded to improve the speaking skills of the $12^{\text {th }}$ grade students. The research was carried out in two cycles and effective in improving the students' pronunciation, grammatical mastery, vocabulary, fluency and confidence. With using visual aids, the teaching and learning processes became more interactive and communicative. Acting out a dialogue and doing role play in front of the others were able to build the students' self-confidence to speak English. They were excited and also enjoyed doing these activities in front of the class.

It is recommended that in further researches, the researchers can carry out the research in more varied contexts in public, private and international schools where there are more variations in students and teachers to explore and compare the effects of use of visual aids on improvement of speaking competency of students.

\section{REFERENCES}

[1]. D. Supiyati, 'Improving Students' Speaking Skills by Using Audio-Visual Aids in Class I A RSBI SD N Cemara Dua No.13 Surakarta in 2009/2010 Academic Year," Surakarta: Teacher Training and Education Faculty, Sebelas Maret University, Unpublished undergraduate thesis, 2011.
[2]. H. D. Brown, Teaching by Principles, an Interactive Approach to Language Pedagogy. New York: Addison Wesley Longman, 2001.

[3]. S. T. Rodgers and J. Richards, Approaches and Methods in Language Teaching. United Kingdom, Cambridge University Press, 1999.

[4]. P. Subathra, The Audio -Visual Aids in English Teaching, 2012.

[5]. D. Riddell, Teach Yourself: Teaching English as A Foreign/Second Language. London: Hodder \& Stoughton Ltd, 2003.

[6]. E. Barkley, Collaborative LearningTechniques: A journal for College Faculty. USA: JosseyBass, 2005.

[7]. J. Allsop, The Penguin Elementary Picture Composition Book, London: Penguin Group, 1996.

[8]. J. Cunningham, "Making and Using Slides in the ESL Classroom," TESL Canada Journal, vol. 9, no. 1, pp. 67-78, 1991.

[9]. M. Ezidene, The Effect of Using Visual Aids on Second Language Speaking. Lebanese American University, American, 2011.

[10]. R. Gorman \& G. S. Eastman, "I See What You Mean: Using Visuals to Teach Metaphoric Thinking in Reading and Writing," English Journal, vol. 100, no. 1, pp. $92-99,2010$.

[11]. J. Harmer, The Practice of English Language Teaching (4th Ed.). Edinburgh: Pearson Education Limited, 2007.

[12]. J. N. Madhuri, "Use of Audio Visual Aids in Teaching and Speaking", Research Journal of English Language and Literature (RJELAL), vol. 3, no. 2, pp. 112-118, 2013.

[13]. S. L. McKay, Researching Second Language Classrooms. New Jersey: Lawrence Erlbaum Associates, Inc, 2006.

[14]. D. Riddell, Teach Yourself: Teaching English as A Foreign/Second Language. London: Hodder \& Stoughton Ltd, 2003.

[15]. N. Singh, "What are the main advantages of audio visual aids?", 2012. [Online]. Available: http://www.preservearticles.com. [Accessed Apr. 20, 2019].

[16]. S. Arikunto, Procedur Penelitian Suatu Pendekatan Praktik. Jakarta: PT Rineka Cipta, 2013.

[17]. M. D. Mamun, Abdullah Effectiveness of visual Aids in Language Teaching in Tertiary Level. BRAC Institute of Languages (BIL), Dhaka, 2014.

[18]. L. Z. Cooper, "Considerations in cross-cultural use of visual information with children for whom English is a second language," Journal of Visual Literacy, vol. 22, no. 2, pp. 129 -142, 2002. 